\title{
TEACHER STRATEGY IN DEVELOPMENT PROSOCIAL BEHAVIOR OF STUDENTS IN ELEMENTARY SCHOOL
}

\author{
Uus Kuswendi ${ }^{1}$ \\ ${ }^{1}$ IKIP Siliwangi \\ ${ }^{1}$ uuskuswendi38@gmail.com
}

\begin{abstract}
Entering the digital age all information cannot be selectively displayed. Freedom in the digital age can affect the behavior patterns of students whether positive behavior or negative behavior. In an effort to prevent the emergence of negative behavior in students, it requires an environment that shapes good behavior such as prosocial behavior. Prosocial behavior really needs to be developed to prevent moral degradation. The formation of prosocial behavior can be done in a student environment such as at school. This study aims to analyze the teacher's strategy in developing students' prosocial behavior in religious-based elementary schools. The research applied a qualitative approach within the case study method. The researcher involved the teacher as the research subject who located in the city of Bandung. The data collection techniques used observation, interviews, and documentation. Then, the validity of the data used triangulation techniques while the data is analyzed through thematic analysis. The finding of the research showed that there is a teacher strategy to develop prosocial behavior of students in religious based elementary schools. Giving motivation and modeling strategy are the teacher's strategy that most widely shown.
\end{abstract}

Keywords: elementary school, prosocial, teacher's strategy.

\begin{abstract}
Abstrak
Memasuki era digital segala informasi tidak dapat ditampilkan secara selektif. Kebebasan di era digital dapat berpengaruh pada pola perilaku siswa baik itu perilaku positif atau perilaku negatif. Sebagai upaya mencegah munculnya perilaku negatif pada siswa maka ia memerlukan lingkungan yang membentuk perilaku baik seperti perilaku prososial. Perilaku prososial sangat perlu dikembangkan untuk mencegah adanya degradasi moral. Pembentukan perilaku prososial dapat dilakukan di lingkungan siswa seperti di sekolah. Penelitian ini bertujuan untuk menganalisis strategi guru dalam pengembangan perilaku prososial siswa di sekolah dasar berbasis agama. Penelitian menerapkan pendekatan kualitatif dengan metode studi kasus. Peneliti melibatkan guru selaku subjek penelitian yang berlokasi di Kota Bandung. Adapun teknik pengumpulan data menggunakan observasi, wawancara, dan dokumentasi. Kemudian, uji validitas data menggunakan triangulasi teknik sedangkan data dianalisis melalui analisis tematik. Hasil penelitian menunjukkan bahwa terdapat strategi guru untuk mengembangkan perilaku prososial siswa di sekolah dasar berbasis agama. Strategi guru yang paling banyak ditunjukkan yaitu strategi pemberian motivasi dan modelling.
\end{abstract}

Kata Kunci: sekolah dasar, prososial, strategi guru

\section{INTRODUCTION}

The educational environment for students in the digital age is no longer limited to school or educational institutions. Students may be in a school environment, but now they have access to twine relation with the others and can be joined theirself in another world through the use of technology and information media. At present, the educational environment has a broader definition that is not only where the student or children lives, but also includes where they find their self as a meaningful person. Students easily find a different place, atmosphere, 
environment, and can identify a situation which is suitable or not suitable for themselves (Muthohar, 2013).

On the other hand, the emergence of the digital era can trigger negative influences on students' lives, especially on character and mental changes. Students' aggressive attitudes and physical violence with each other are interconnected phenomena. The preaching of elementary school students who carried out abuse with elements of physical violence often appeared on television and online media as a result of online games with elements of violence. Access to pornography and porno-action make students experience alarming mental changes, especially in relationships that lead to free sex (Setiawan, 2017). The decline of student values is indeed a serious concern of the government and society. However, the rapid flow of information technology in the digital era which is quite difficult to stem makes the problem not simple. Media without control can easily brainwash students through online games. Students are more interested in their cellphones than playing traditional games, listening to tales, and singing children's songs that are full of education. Furthermore, the advertisements of illicit goods such as alcohol and narcotics are packaged attractively through the internet in the form of online games, adding to the complexity of student morality issues (Setiawan, 2017).

The issue of morality that is increasingly developing can lead to degradation or decline in students' moral. The issue of moral degradation is prone to students because they have not been able to filter every case properly in their society (Safaria \& Saputra, 2009). This raises concerns about the behavior of the next generation of low morality. In addition, moral degradation resulted in the loss of mutual cooperation, mutual assistance, greeting, or courtesy. Referring to the problems described previously, the researcher concludes that every elementary school needs to be involved to develop students' prosocial behavior.

Prosocial behavior is a feeling of caring that is demonstrated through various behaviors such as sharing, helping, or cooperating to benefit others or someone in the group (Rowley et al., 2014). Prosocial behavior aims to help others without expecting rewards (Walker \& Carlo, 2014). Prosocial behavior is important to note because prosocial behavior can prevent students from doing deviant or aggressive behavior (Carlo, 2014). Elementary students like imitating and try new things so prosocial behavior is very important to develop. If students live in an environment that supports prosocial behavior, they will grow into a moral person. Therefore, the development of students' prosocial behavior needs to be done to shape the personality of students who are mentally healthy so that the problem of moral degradation decreases. 
Efforts to develop students' prosocial behavior can be done through school programs. Schools have a significant contribution to the development of students' prosocial behavior. Schools need to create a conducive environment so students can behave according to religious norms and society. The spread of religion-based schools attracted parents to send their children to school at the school. Parents hope that children will receive education in religious based schools so they will prevent them from the magnitude of the negative impact in the digital age today. The religious based school system usually applies Full day or one-day school. Parents' view of the emergence of the full day school is better for children to spend time in school because their behavior is monitored by school residents.

Prosocial behavior should indeed be developed sustainably so it will be integrated into students' behavior. Development of prosocial behavior can be done by parents and teachers. This is because parents and teachers have the closest relationship with the children. Parents apply prosocial behavior at home and the environment while teachers apply prosocial behavior at school. Parents and teachers need to work together in developing prosocial behavior so that children have a role model for prosocial behavior. According to Eisenberg \& Mussen (1997), the teacher's strategy in developing prosocial behavior can be done through motivation, modeling, class or school discipline, and social action. Referring to the previous presentation, the researcher is interested in conducting research with the aim of analyzing the teacher's strategy in developing students' prosocial behavior at religious-based elementary schools.

\section{METHOD}

This research used a qualitative research approach with a case study method. Qualitative research is carried out because it intends to explore a phenomenon. In line with Crowe, et al (2011), the case study method is useful for exploring issues or phenomena in depth in a natural context using various data collection techniques. The issue and phenomenon in this research relate to the teacher's strategy in developing students' prosocial behavior in religiousbased elementary schools. Case study research has three types of studies, namely intrinsic case studies, instrumental case studies, and collective case studies (Stake, 2005). This research is an intrinsic case study because it aims to understand more deeply about the efforts of teachers to develop prosocial behavior of students in religious-based elementary schools. The research is located in one of the Bandung based religious schools. The reason for choosing a religion based elementary school is because the school has a mission to form noble character in students. Researcher indicated that the school had strategies related to the development of students' prosocial behavior. 
Furthermore, this research involved the teacher as research subjects. This is because the teacher acts as a base informant who can provide a number of important information about the focus of research studies. The data collection techniques in qualitative research are carried out with natural conditions (Jenkins, 2016). Moreover, research data collection techniques were participant observation, in-depth interviews, and documentation both from primary or secondary data sources. Data analysis in this research used a qualitative approach with thematic analysis techniques. Naughton \& Hughes (2009) states that thematic analysis is a data analysis technique that is carried out by looking at and finding themes and categories obtained in data that has been coded first. The stages of data analysis in this study were (a) preparing raw data; (b) coding; (c) code classification; (d) interpretation of data; (e) presentation of data (Creswell, 2013).

\section{RESULTS AND DISCUSSION}

Researchers conducted observations, interviews, and documentation studies to identify teacher strategies in developing prosocial behavior in religious-based elementary schools. Based on observations, interviews, and documentation studies, the researchers concluded that the teacher's strategy in developing students' prosocial behavior included giving motivation, modeling, enforcing discipline, and social action. The strategy for developing prosocial behavior that emerged in this research refers to the opinion of Eisenberg \& Mussen (1997). The findings of the study on the strategies for developing prosocial behavior of students in religious-based elementary schools are described in table 1 below.

Table 1. Research Findings on Prosocial Behavior Development Strategies

\begin{tabular}{|c|c|c|}
\hline \multicolumn{3}{|c|}{ Strategy for Giving Motivation } \\
\hline No & Indicator & Phenomenon \\
\hline 1. & $\begin{array}{l}\text { The teacher encourages students to } \\
\text { carry out prosocial behavior. }\end{array}$ & $\begin{array}{l}\text { a. The teacher gave an explanation of } \\
\text { finding an item, it must be returned to the } \\
\text { owner. } \\
\text { b. Teachers explained when doing good } \\
\text { then will be rewarded by God and } \\
\text { doubled. } \\
\text { c. The teacher gave the opportunity for } \\
\text { students to tell stories during the end of } \\
\text { the holidays. }\end{array}$ \\
\hline & $\begin{array}{l}\text { The teacher gives rewards to both } \\
\text { material and immaterial to students } \\
\text { who are prosocial. }\end{array}$ & $\begin{array}{l}\text { a. The teacher gave praise to students who } \\
\text { act honestly. } \\
\text { b. The teacher bought students food } \\
\text { because they have behaved well. }\end{array}$ \\
\hline
\end{tabular}




\begin{tabular}{|c|c|}
\hline $\begin{array}{l}\text { 3. The teacher rebukes and advises } \\
\text { students who behave antisocially. }\end{array}$ & $\begin{array}{l}\text { The teacher advised students who are } \\
\text { antisocial }\end{array}$ \\
\hline
\end{tabular}

\begin{tabular}{lll}
\hline \multicolumn{3}{c}{ Modeling Strategy } \\
\hline No & \multicolumn{1}{c}{ Indicator } & \multicolumn{1}{c}{ Phenomenon } \\
\hline 1. & $\begin{array}{l}\text { The teacher shows learning videos } \\
\text { about prosocial behavior. }\end{array}$ & $\begin{array}{l}\text { The teacher showed the sacrificial education } \\
\text { video. }\end{array}$ \\
\hline $\begin{array}{l}\text { The teacher gives examples of } \\
\text { prosocial behavior to students, both in } \\
\text { speech and deeds. }\end{array}$ & The teacher shared food with students. \\
\hline
\end{tabular}

\begin{tabular}{lll}
\hline \multicolumn{4}{c}{ Strategy for Enforcement of Rules of Procedure } \\
\hline No & \multicolumn{1}{c}{ Indicator } & \multicolumn{1}{c}{ Phenomenon } \\
\hline 1. & The teacher socializes the order. & $\begin{array}{l}\text { a. The teacher socialized the rules through } \\
\text { the parenting program. }\end{array}$ \\
\hline $\begin{array}{l}\text { Teachers carry out school rules that are } \\
\begin{array}{l}\text { appropriate, } \\
\text { supervised. }\end{array}\end{array}$ & $\begin{array}{l}\text { a. Students were not allowed to take } \\
\text { cellphones to school. }\end{array}$ \\
\hline
\end{tabular}

\begin{tabular}{llll}
\hline \multicolumn{4}{c}{ Strategy for Social Action } \\
\hline No & \multicolumn{1}{c}{ Indicator } & \multicolumn{1}{c}{ Phenomenon } \\
\hline $\begin{array}{l}\text { The teacher invites students to set aside } \\
\text { part of their money for social } \\
\text { donations. }\end{array}$ & $\begin{array}{l}\text { a. } \\
\text { b. }\end{array}$ & $\begin{array}{l}\text { The teacher invited students to did Infaq } \\
\text { The teacher invited students to set aside } \\
\text { pocket money as a form of condolences. }\end{array}$ \\
\hline $\begin{array}{l}\text { The teacher invites students to visit the } \\
\text { orphanage to share happiness. }\end{array}$ & $\begin{array}{l}\text { The teacher invited the students to love } \\
\text { orphans. }\end{array}$ \\
\hline
\end{tabular}

The findings of this research are in line with the findings of McCarty et al. (2016) about the efforts made by teachers in developing prosocial behavior which includes (1) socializing the importance of prosocial behavior and working together to develop prosocial behavior with stakeholders; (2) displaying prosocial behavior videos as a form of motivation and modeling; (3) implementing learning that is integrated with character education.

The first strategy that often arises in developing students' prosocial behavior is giving motivation. Giving motivation is done by the way the teacher gives rewards in the form of praise and invites students to eat together. Warneken \& Tomasello (2008) prove that giving rewards can materially motivate students to behave in ways that help, share, and cooperate. The Warneken \& Tomasello statement is in accordance with the efforts made by the teacher in 
this study. The strategy by the teacher is to give rewards both material and immaterial to students who have prosocial behavior. Giving rewards is categorized into aspects of giving motivation in developing prosocial behavior. The reward given by the teacher has an impact on student behavior. For example, students share food with their friends. Such behavior is inspired by the behavior of teachers who sometimes intentionally bring a lot of food to eat together. When viewed from this phenomenon, the role of the teacher as an exemplary figure in school affects the daily behavior of students. Correspondingly, Mayers \& Morris (2009) states that prosocial behavior will be formed in schools if the teacher shows prosocial behavior to students.

The teacher's strategy in developing the following prosocial behaviors is modeling. Modeling is the teacher's effort in developing prosocial behavior through concrete actions so that students can assess and apply these actions in their lives. Modeling by the teacher appears in order to celebrate Eid al-Adha. The teacher displays videos about sacrificial education so students can take lessons from the sacrificial celebration. Students watched sacrificial educational videos in the school hall guided by religious teachers. Students watched sacrificial animal slaughter until the meat is distributed by the teacher. Due to a number of obstacles, to commemorate Eid al-Adha, the event at the school only shows the Eid al-Adha activities carried out by the teacher, recitation, and enjoying meals together.

The findings of this research are in line with the research of Hasegawa, et al. (2016) who found that educational video shows had an impact on the prosocial behavior of elementary school students. Hasegawa, et al. (2016) carry out research by filling out questionnaires and observations. Students who often watch educational videos show prosocial behavior to their peers. Students imitate the scenes in educational videos in real life. Students who often watch educational videos show more prosocial behavior than students who rarely watch videos. Examples of scenes that students emulate in school are generous behavior. A group of students played together while carrying supplies and they shared their provisions. Then, the remaining provisions students share with friends who are playing around it.

In line with that, Perry \& Furukawa (in Maemun, 2012) states that modeling techniques are a component of a strategy where the counselor provides a demonstration of the behavior that is the goal. Furthermore, Taufik (2009) suggested that modeling techniques were given by the way clients observe others as models to be emulated. Then the client is given reinforcement if he is able to model the given model. This is mainly done to obtain social skills behavior. The results obtained from modeling techniques make students more motivated to be more prosocial 
by discussing prosocial topics that have been witnessed from the symbolic models being watched, thus supporting the increase in prosocial behavior of students (Putra, Gistituati, \& Syahniar, 2015).

The teacher's strategy in developing further prosocial behavior is social action. Social action is included in routine programs and annual programs organized by the school. Social action as a routine program is conducted once a week on Fridays. Meanwhile, social action in the annual program is carried out during the Eid al-Adha celebration and the 10th anniversary of Muharram or Ashura. During the Eid al-Adha celebration, the school held a social action activity by distributing sacrificial meat to the community. When the 10th anniversary of Muharram school held a social action in the form of compensation for orphans.

The research findings are in line with previous studies conducted by Alam (2016) on the effect of Friday's Infaq activities on prosocial behavior of fifth-grade students of elementary school. The findings of this research showed that Friday's Infaq activity had an effect on students' prosocial behavior which was generous. Students who are accustomed to infaq on Friday do not object if they have to set aside their allowance to donate or do social action. Students believe that the money they set aside will benefit others so that if there are sudden social actions, they can easily share.

Enforcement of school discipline is a form of teacher strategy in developing prosocial behavior. Enforcement of school discipline aims to make school citizens behave in accordance with the regulations so that the vision, mission, and goals of the school are achieved. Enforcement of the first order must be demonstrated by the teacher so that students are motivated to take the same actions as the teacher. Enforcement of order is not only socialized to students but to parents so that cooperation between parents and the school is established.

One of the rules that aim to develop students' prosocial behavior is the prohibition of taking cellphones to school for students and the prohibition of taking cellphones to class for teachers. The reason students are prohibited from taking cellphones to school is so that students concentrate on learning and increase interaction with those around them. If you are allowed to bring a cellphone to school, students will prefer to play cellphones rather than learning and playing with friends. Furthermore, the ban on carrying mobile phones aims to prevent students from cybercrime and prevent students from opening pornographic content. Prohibition of bringing cellphones into the classroom applies to teachers so as not to interfere with learning. This ban is imposed because the teacher is the figure who becomes the student role model. If the teacher does not bring the cellphone into the classroom, students will easily accept the 
prohibition on carrying a cellphone. However, if the teacher is allowed to bring a cellphone, students can sue the school to allow students to bring a cellphone. Therefore, the school made an order in the form of a ban on carrying cellphones for students and teachers.

Students need to be accustomed to prosocial behavior early. Students will have good internal control if they are in a school environment with teachers who are full of warmth and love. Students will be better if they grow up in an environment with severe physical punishment. This is because there is a crucial pattern of interaction between teachers and students. Students who have prosocial behavior are influenced by the prosocial behavior shown by the teacher. Therefore, teachers need to be a good model for their students (Bashori, 2017). The closeness of the teacher's relation with students has an important role in internalizing prosocial values. The teachers' authority and closeness to their relationship with students will strengthen their referent power. Referent power is a power obtained on the basis of admiration, exemplary, charisma and personality of a figure. If the teachers can portray their self as a prosocial ideal model, it will have a good impact on the development of students' prosocial behavior (Bashori, 2017).

\section{CONCLUSION}

Prosocial behavior is a feeling of caring that is demonstrated through various behaviors such as helping, helping, or cooperating so as to benefit others or someone in the group. Prosocial behavior aims to help others without expecting a reward. Prosocial behavior is important to note because prosocial behavior can prevent students from doing deviant or aggressive behavior. Various strategies can be carried out to develop students' prosocial behavior such as the strategies carried out by teachers in schools. The results of this study indicate that there are several strategies by teachers in developing students' prosocial behavior in religious-based elementary schools. The strategies carried out by the teacher are motivation, modeling, enforcement of the order, and social action.

Giving motivation is done by the teacher through reward in the form of praise or material such as inviting students to eat together. Then the enforcement strategy is integrated with modeling strategies. In this study, the teacher behaves in accordance with the existing rules in the school so that students also behave according to the order. Furthermore, the strategy for social action is carried out through infaq activities on Friday and making donations to orphans. The teacher is a figure who is close to students so that their existence can influence their lives. Therefore, the teacher acts as a figure for students both in behaving or speaking. 
Thus, prosocial behavior will be easily embedded in students if the teacher also shows prosocial behavior.

\section{ACKNOWLEDGMENTS}

Thank you to both parents, Vina A.N. Ariawan, Prof. Dr. H. Disman, M.S. and Dr. M. Solehuddin, M. Pd., M.A who have given prayer, knowledge, guidance, assistance, enthusiasm, motivation, and relentless support so that this research can be completed properly.

\section{REFERENCES}

Alam, R.B. (2016). Pengaruh kegiatan rutin infaq setiap hari Jumat terhadap perilaku prososial siswa kelas Vdi SD Negeri Bantarkawung 01 Tahun Pelajaran 2015/2016. Universitas Peradaban.

Bashori, K. (2017). Menyemai perilaku prososial siswa di sekolah. SUKMA: Jurnal Pendidikan, 1 (1): 57-92.

Carlo, G. (2014). The development and correlates of prosocial moral behaviors. In M. Killen \& J. G. Smetana (Eds.), Handbook of moral development (2nd ed., pp. 208-234). New York, NY: Psychology Press.

Creswell, J.W. (2013). Research design: Pendekatan kualitatif, kuantitatif, dan mixed. Yogyakarta: Pustaka Pelajar.

Crowe, S., et al. (2011). The case study approach. BMC Medical Research Methodology, 11(1): pp. 100 .

Eisenberg, N. \& Mussen, P.H. (1997). The roots of prosocial behavior in children. Cambridge : Cambridge University Press.

Hasegawa, M., et al. (2016). A two-wave panel investigation of the influence of viewing prosocial behaviour on television on the sociality of elementary school children in Japan. Media Asia, 39 (4): 216-228.

Jenkins, M.P. (2016). Problematizing ethnography and case study: reflections on using ethnographic techniques and researcher positioning. Ethnography and Education, 1-18.

Maemun, A. (2012). Pengembangan Model Bimbingan Kelompok dengan Teknik Modeling untuk Mengembangkan Budi Pekerti Berbasis Nilai-Nilai Humanistik. Jurnal Bimbingan Konseling, I (1): 1-10.

Mayers, S. \& Morris, A. (2009). Examining associations between effortful control and teacherchild relationships in relation to head start children's socioemotional adjustment. Early Education and Development, 20: 756-774.

McCarty, S., et al. (2016). Actively caring to prevent bullying in an elementary school: Prompting and rewarding prosocial behavior. Journal of Prevention \& Intervention in the Community, 44 (3): 164-176.

Muthohar, S. (2013). Antisipasi Degradasi Moral di Era Global. Nadwa Jurnal Pendidikan Islam, 7 (2): 321-334.

Naughton, G.M \& Hughes, P. (2009). Doing action research in early childhood studies: a step by step guide. USA: Open University Press. 
Putra, H.P., Gistituati, N., Syahniar. (2015). Peningkatan perilaku prososial siswa di sekolah melalui layanan bimbingan kelompok dengan teknik modeling. Jurnal Konseling dan Pendidikan, 3 (2): 31-39.

Rowley, S. J., et al. (2014). Framing Black Boys: Parent, Teacher, and Student Narratives of the Academic Lives of Black Boys. The Role of Gender in Educational Contexts and Outcomes, 47: 301-332.

Safaria \& Saputra. (2009). Manajemen emosi. Yogyakarta : Bumi Aksara.

Setiawan, W. (2017). Era digital dan tantangannya. Seminar Nasional Pendidikan. Universitas Muhammadiyah Sukabumi.

Stake R. (2005). Qualitative Case Studies in Denzin, N.K. \& Lincoln, Y.S. (eds.) The Sage Handbook of Qualitative Research (3rd ed.). Thousand Oaks/London/New Delhi: Sage Publications.

Taufik. (2009). Model-model konseling. Padang: Fakultas Ilmu Pendidikan UNP.

Walker, L. M. P., \& Carlo, G. (2014). Prosocial Development a Multidimensional Approach. Oxford : University Press.

Warneken, F., \& Tomasello, M. (2008). Extrinsic rewards undermine altruistic tendencies in 20-month-olds. Dev Psychol, 44 (6), 1785-1788. 